\title{
Distribution Profile and Function of Carbohydrate Residues in Testes of Immature and Mature Sunda Porcupine (Hystrix javanica)
}

\author{
Teguh Budipitojo $^{1}{ }^{*}$, Irma Padeta $^{1}$, Beninda U. Yulianti ${ }^{1}$ and Dian B. H. Masithoh ${ }^{2}$ \\ ${ }^{1}$ Department of Anatomy, Faculty of Veterinary Medicine, Universitas Gadjah Mada, Yogyakarta 55281, Indonesia \\ ${ }^{2}$ Doctoral student of Veterinary Science, Faculty of Veterinary Medicine, Universitas Gadjah Mada, Yogyakarta 55281, Indonesia \\ *Corresponding author's Email: budipitojo@ugm.ac.id; (1) ORCiD: 0000-0003-1464-1602
}

\begin{abstract}
The population of Sunda porcupine (Hystrix javanica) declines each year since it is rarely found in nature. The present study aimed to obtain information about the distribution of carbohydrate residues contained in immature and mature of Sunda porcupine's testes and to discuss its relevant functions. This study used six testes obtained from four immature and two mature Sunda porcupine originated from Ngawi Regency, East Java Province, Indonesia. Testis tissues were stained with hematoxylin and eosin and lectin histochemistry of Lens culinaris agglutinin (LCA), Phaseolus vulgaris leucoagglutinin (PHA-L), Pisum sativum agglutinin (PSA), Sophora japonica agglutinin (SJA), and Wheat germ agglutinin (WGA). Data were analyzed with descriptive and semi-quantitative method. Lectin histochemical staining with LCA, PHA-L, SJA, PSA, and WGA indicated the presence of alpha-D-mannose and alpha-D-glucose, $\mathrm{N}$-acetylgalactosamine, mannose, and $\mathrm{N}$-acetylglucosamine residues in the immature and mature testes with weak to very strong intensity. In the immature testes of Sunda porcupine, there was positive reactivity with PHA-L for Leydig and Sertoli cells, $\mathrm{N}$-acetylgalactosamine may play an important role in the development and maturation of Leydig and Sertoli cells. Mature testes showed a strong positive reaction to the LCA, SJA, PSA, and WGA which indicated the significant roles of alpha-D-mannose and alpha-D-glucose, N-acetylgalactosamine, mannose, and $\mathrm{N}$-acetylglucosamine residues on the maturation process of early spermatid to the late spermatid. These results can be used as basic data to be implemented in the conservation efforts of Sunda porcupine.
\end{abstract}

Key words: Carbohydrate residue, Lectin, Spermatogenesis, Sunda porcupine, Testes

\section{INTRODUCTION}

Hystrix javanica is an Indonesian endemic porcupine, commonly called the Sunda porcupine. Taxonomy of Sunda porcupine is: kingdom Animalia, phylum Chordata, class Mammalian, order Rodentia, family Hystricidae, genus Hystrix and species $H$. javanica. Based on the International Union for Conservation of Nature (IUCN), Sunda porcupine is classified in least-concern category which means that is still relatively spread, abundant and no major threat to the existence of Sunda porcupine. The Convention on International Trade in Endangered Species (CITES) which regulates the trade of endangered species of wildlife and plants, includes the Sunda porcupine in the appendix III list which means it has not been considered endangered category (Aplin, 2016).

Testes are reproductive organs that amount to one pair. The testes are in the scrotum and enveloped by tunica albuginea. The seminiferous tubules are present in the testes bounded by complex epithelium of spermatogenic cells and Sertoli cells. Spermatogenic cells produce spermatozoa (Bacha Jr and Bacha, 2012). The Sertoli cell is located in the terminal segment of the seminiferous tubule having functions as fluid transport and secretory activity as well as phagocytosis and intracytoplasmic spermatozoa degradation (Ahmed, 2005). The Sertoli cell has a pale or triangular nucleus that is a high cell extending from the basement membrane to the tubular lumen (Bacha Jr and Bacha, 2012). Interstitial tissue fills the space between seminiferous tubules with blood vessels, lymph vessels, and nerves of the testicular parenchyma (Setchell, 1986). Leydig cells are a very important source of androgens. More than $90 \%$ of the androgens in the organism are produced in testes (Ahmed, 2005).

Lectins can be defined as non-immune carbohydrate-binding proteins that can agglutinate and or form the precipitates of glycoconjugate. Glycoconjugates play a role in cell differentiation, cell maturation, cell recognition, cell adhesion, and cell interactions. The distribution of glycoconjugates in animal tissues can be investigated using histochemical lectin staining (Dias et al., 2015). 
Information on testicular biology of Sunda porcupine has not been previously reported. Limited data on the reproductive biology of Sunda porcupine was an important reason for this study. This information can be used to support Sunda porcupine breeding efforts in Indonesia. The aim of this study was to provide Information on carbohydrate residues of immature and mature testes of Sunda porcupine to determine the role of glycoconjugate in the spermatogenesis process.

\section{MATERIALS AND METHODS}

This study used the testes from the male Sunda porcupine (two adults and four immature) originated from Ngawi, East Java, Indonesia. Testes samples were trimmed by dividing three parts of the testis according to the location of epididymis which is caput, corpus, and cauda.

\section{Hematoxylin and eosin staining}

Conventional Hematoxylin and Eosin (H\&E) staining, which has been used by histologists for more than 100 years, is the gold standard of histology structure (Li et al., 2018). The first stage of H\&E staining was deparaffinization. The slides were dipped into the Harris Hematoxylin solution then dipped into the eosin solution. The next step was dehydration. The clearing process was done by inserting the slides into xylene. The mounting process was done by closing the tissue using glass decks and Entellan as an adhesive.

\section{Lectin histochemical staining}

The first step of lectin histochemical staining was deparaffinization with xylene and rehydration with ethanol. The slides were incubated in $3 \% \mathrm{H}_{2} \mathrm{O}_{2}$ solution in methanol as endogenous peroxide inhibitor for 30 min and wash with PBS, then background sniper was applied to block non-specific proteins for $30 \mathrm{~min}$. Fifteen microliter solution of Lens culinaris agglutinin (LCA), wheat germ agglutinin (WGA), Sophora japonica agglutinin (SJA), Phaseolus vulgaris leucoagglutinin (PHA-L), Pissum sativum agglutinin (PSA) and PBS was dropped as a negative control, then incubated overnight in $4^{0} \mathrm{C}$. The positive reaction of lectins was visualized by diaminobenzidine (DAB) substrate, followed by Hematoxylin Harris solution for counterstain. Then slides were dehydrated with ethanol, cleared with xylene and mounted. The semi-quantitative analysis as a parameter was based on the brown color visualized in the cells with five criteria as negative $(-)$, weak $(+)$, moderate $(++)$, strong $(+++)$, and very strong $(++++)$.

\section{RESULTS AND DISCUSSION}

Lectins play an important role in the processes associated with the recognition and interaction of cells, protein synthesis and transport, cell division regulation, fertilization, innate immunity, etc. (De Schutter and Van Damme, 2015; Feizi and Haltiwanger, 2015). Lectins are specific to certain carbohydrate structures. Some lectins can interact only with mannose or glucose residues and others only with galactose. There are other lectins specific to fucose, sialic acid, and other monosaccharides (Kobayashi et al., 2014; Nagdas et al., 2014).

The LCA reactivities on mature Sunda porcupine testicles detected strong on the early spermatids in caput (Figure 1A), corpus (Figure 1B), and cauda (Figure 1C). LCA reactivities detected on late spermatids only in caput (Figure 1A). The LCA reactivity was not shown in spermatogonia, primary spermatocytes, early spermatids, late spermatids, Leydig cells and testicular Sertoli cells in the caput (Figure 1D), corpus (Figure1E), and cauda (Figure 1F) in immature Sunda porcupine. According to Barre et al. (2019), LCA is specific to detect alpha-D-mannose and alpha-D-glucose sugar residues. Lectin histochemical staining of LCA in mature male Sunda porcupine detected in early spermatid and late spermatid shows that alpha-D-mannose and alpha-D-glucose sugar residues are needed at the early stages until the final stage of spermatid differentiation. While, lectin histochemical staining of LCA not detected in immature testicles indicates that the immature Sunda porcupine testicles did not require alpha-D-mannose and alpha-D-glucose sugar residues. Research on mice (Lee and Damjanov, 1984) showed different results in which LCA reacted positively to Sertoli cells, spermatogonia, spermatocytes, spermatozoa, and Leydig cells.

The PHA-L reactivity on mature Sunda porcupine was detected weak to testicular spermatogonia in corpus (Figure 2B), and negative in caput (Figure 2A) and caudal (Figure 2C). In late spermatid, PHA-L reactivities were weak in corpus (Figure 2D). Reactivity of PHA-L in Leydig cells was weak in caput (Figure 2A) and corpus (Figure 2C). Immature Sunda porcupine, PHA-L in Leydig cells showed positive reactivity in caput (Figure 2D), and weak reactivity in corpus (Figure 2E). Sertoli cells showed weak PHA-L reactivity in caput and corpus. According to Zhang et al. (2014), PHA-L bound N-acetylgalactosamine. Lectinhistochemical staining PHA-L detected in Leydig cells, spermatogonia, and late spermatids on mature and immature Sunda porcupine shows that N-acetylgalactosamine sugar residues are required in the process of differentiation and maturation of these cells. According to Arya and Vanhaperttula (1985), the need for glycoconjugate in small portions of Sertoli cells is thought to be closely related to the 
phagocytic ability and the process of forming residual bodies in the final stages. According to Ahmed (2005), Leydig cells are an important source of androgen hormones and $90 \%$ of the androgen hormones in the animal body are produced by the testes. N-acetylgalactosamine sugar residue is required for optimal development of Leydig cell so that Leydig cells can produce testosterone. PHA-L staining in mice (Lee and Damjanov, 1985) showed that PHA-L reacted positively to spermatogonia, spermatocytes, spermatids, and spermatozoa.

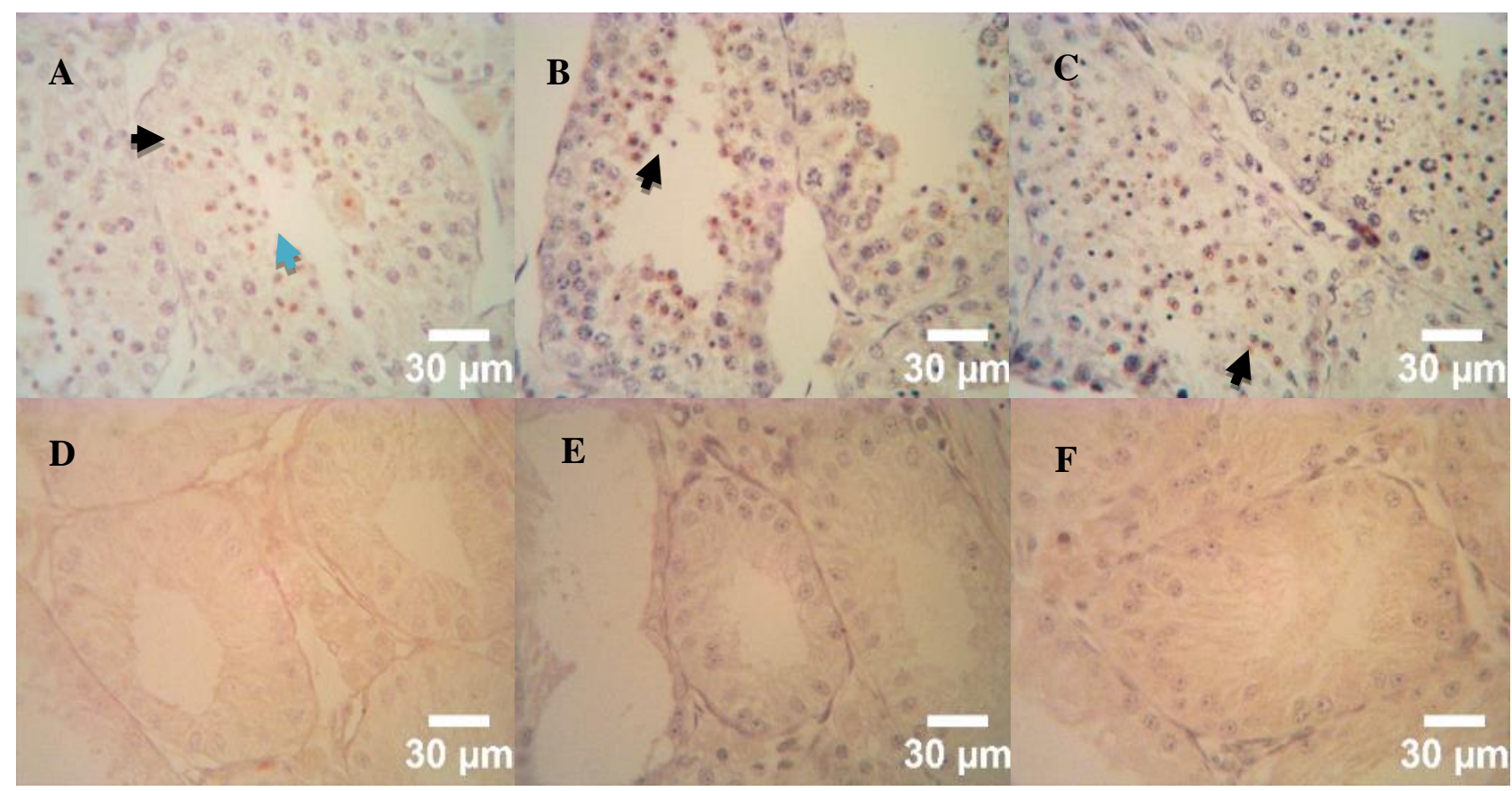

Figure 1. Testicular micrographs of Hystrix javanica (lectin histochemical staining with LCA). A: positive LCA reactivity in the early spermatid (black arrow) and the late spermatid (blue arrow) in caput of the mature Sunda porcupine testicle. B: LCA reactivity in the early spermatid (black arrow) in corpus of the mature Sunda porcupine testicle. C: LCA reactivity in the early spermatid (black arrow) in cauda of the mature Sunda porcupine testicle. Negative LCA-reactivity in caput $(\mathbf{D})$, corpus $(\mathbf{E})$ and cauda $(\mathbf{F})$ regions of immature Sunda porcupine's testicle.

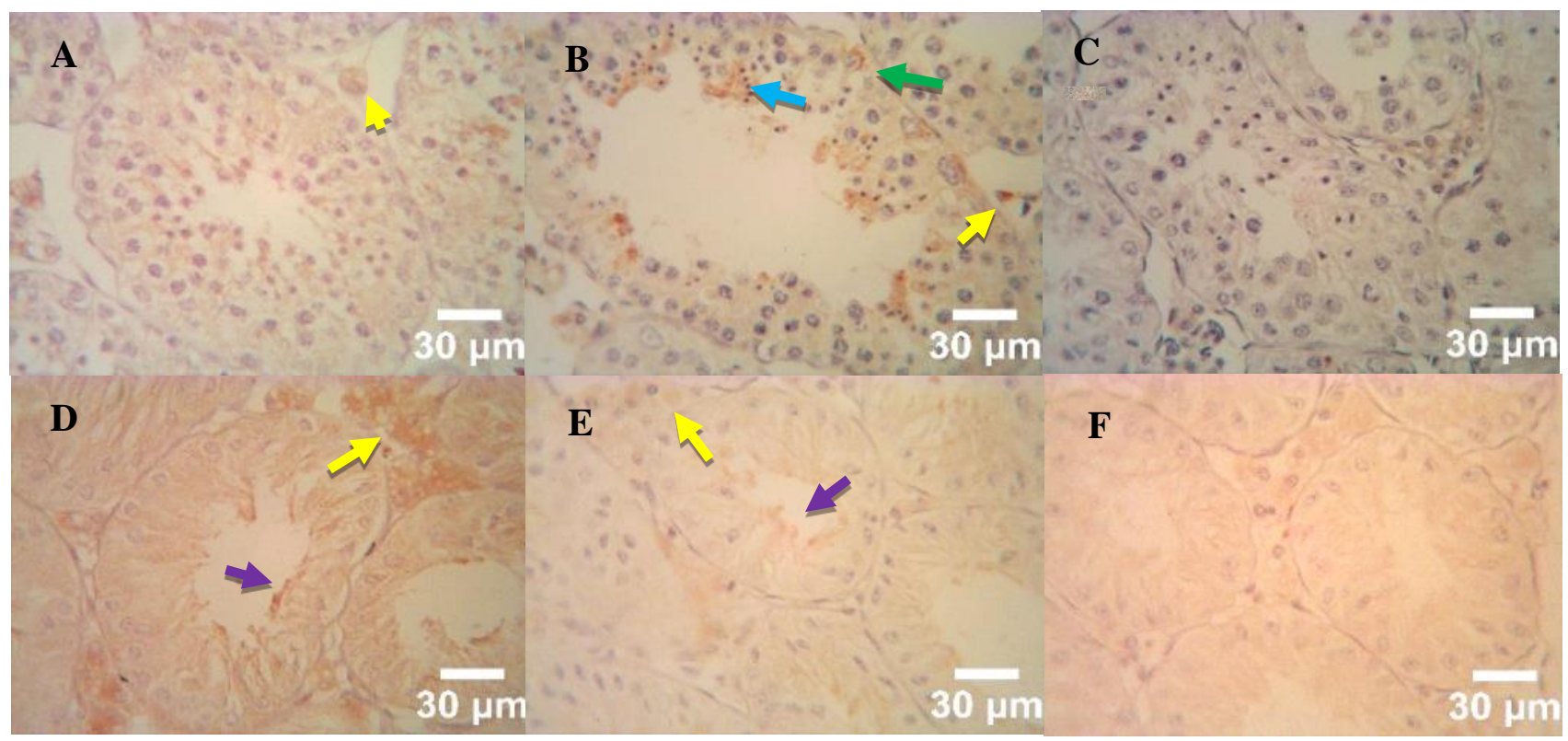

Figure 2. Testicular micrographs of Hystrix javanica (lectin histochemical staining with PHA-L). A: positive lectin reactivity in Leydig cells (yellow arrow) of testicle of mature Sunda porcupine in caput region. B: positive lectin reactivity in spermatogonia (green arrow), late spermatid (blue arrow) and Leydig cell (yellow arrow) of mature Sunda porcupine in corpus region. C: negative lectin reactivity in caudal region of mature Sunda porcupine testicle. D: PHA-L reactivities detected in Leydig cells (yellow arrow) and Sertoli cell cytoplasm (purple arrow) of immature Sunda porcupine testicle. E: an immature Sunda porcupine testicle in the corpus show positive PHA-L reactivities in the Leydig (yellow arrow) and Sertoli cell cytoplasm (purple arrow). F: the immature Sunda porcupine testicle in cauda showing negative PHA-L reactivity. 
Lectin histochemical staining with PSA for primary spermatocytes of mature Sunda porcupine showed week reactivity in cauda region (Figure 3C). PSA reactivity was detected moderate in primary spermatocyte, early spermatid in caput region (Figure 9A) and weak in corpus (Figure 3B) and cauda (Figure 3C). PSA reactivity was detected moderate in late spermatid in caput (Figure 3A), and weak in cauda (Figure 3C). Lectin histochemical staining with PSA of testis of immature Sunda porcupine showed weak reactivity in Leydig cells in caput (Figure 3D). According to Zhang et al. (2014), lectin histochemical PSA binds to mannose. PSA reacted positively to primary spermatocytes, early spermatids, and late spermatids of mature Sunda porcupine, and reacted positively to Leydig cells of immature Sunda porcupine. According to Novelina et al. (2010), glycoconjugate plays an important role in various metabolic processes of the body such as regeneration, cell differentiation, adhesion, and intercellular communication as well as other functional processes. Cells that react positively to PSA indicate that the cell requires a residual sugar mannose in its development. According to Wahyuni et al. (2016), the detectable glycoconjugate in spermatids indicates the importance of glycoconjugate in spermatogenesis, especially in spermiogenesis.

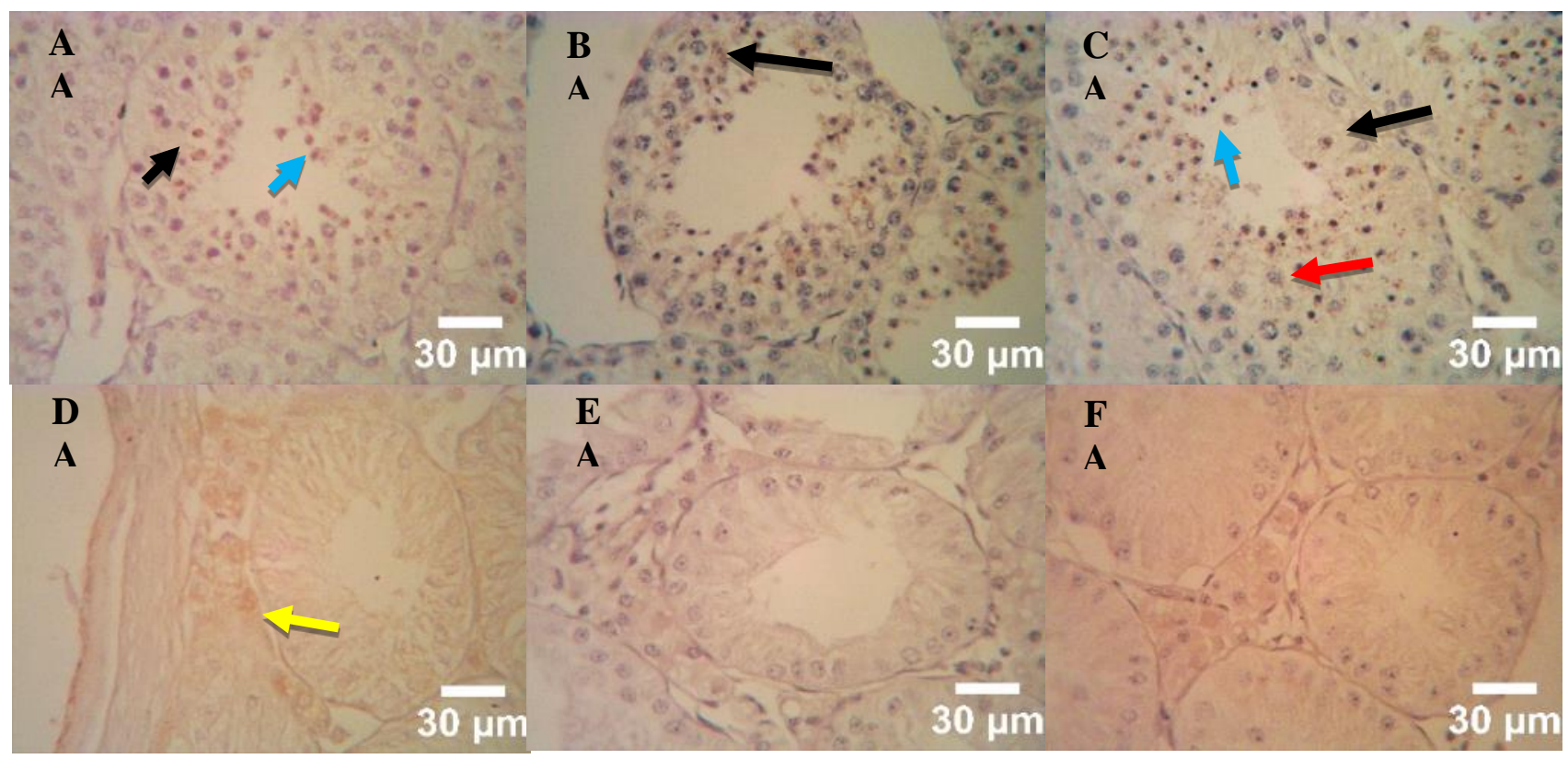

Figure 3. Testicular micrographs of Hystrix javanica (lectin histochemical staining with PSA). A: the testicles of mature Sunda porcupine in caput region showing PSA reactivities in the early spermatid (black arrow) and late spermatid (blue arrow). B: mature Sunda porcupine testicle in the corpus showing PSA reactivities in early spermatid (black arrow). C: testis of mature Sunda porcupine in caudal part showing PSA reactivities in primary spermatocyte (red arrow), early spermatid (black arrow) and the late spermatid (blue arrow). D: the immature Sunda porcupine testicle in caput showing positive PSA-reactivity in Leydig cell (yellow arrow), whereas the negative reactivity in corpus (E) and cauda $(\mathbf{F})$

Histochemical lectin staining with SJA in early spermatids of mature Sunda porcupine showed strong reactivity in cauda (Figure 4C), moderately positive reactions in caput (Figure 4A), and weak reactions in corpus (Figure 4B). The late spermatid showed moderate SJA reactivity in caput (Figure 4A). The immature Sunda porcupine's Leydig cells showed weak SJA reactivity in caput (Figure 4D). According to Zhang et al. (2014), SJA binds N-acetylgalactosamine. SJA showed positive reactions in the early spermatids and late spermatids of mature Sunda porcupine, and immature Sunda porcupine's Leydig cells. Cells that react positively to SJA show that the cell requires N-acetylgalactosamine for its development. The positive pattern was found from the early stage to the late stage of the spermatid. Although in the final stages, the intensity of the positive reaction decreased, the positive affinity pattern of Sunda porcupine was similar to that of the horse (Verini-Supplizi et al., 2000).

Lectin histochemical staining of mature Sunda porcupine showed that WGA reacted positively strong in primary spermatocytes, early spermatids and late spermatids in caput (Figure 5A) and cauda (Figure 5C), whereas in corpus (Figure 5B) was positively weak. In immature Sunda porcupine, WGA reacted positively weak on Leydig cells in the corpus (Figure 5E). According to Wahyuni et al. (2016), WGA binds with N-acetylglucosamine sugar that is necessary for differentiation process of spermatocyte and spermatid cell. WGA reactivity in rats was detected in spermatogonia, spermatocytes, spermatozoa, Sertoli cells, Leydig cells, and lamina propria (Lee and Damjanov, 1985; Shegedin et al., 2017). In Syrian hamster, WGA reactivities were detected in spermatogonia (Hernández et al.2018).

Lectin histochemical staining with LCA, PHA-L, SJA, PSA, and WGA indicated the presence of alpha-D-mannose and alpha-D-glucose, $\mathrm{N}$-acetylgalactosamine, mannose, and $\mathrm{N}$-acetylglucosamine residues (Murakami et al., 2014; Belicky and Tkac, 2015) in the immature and mature testes. 


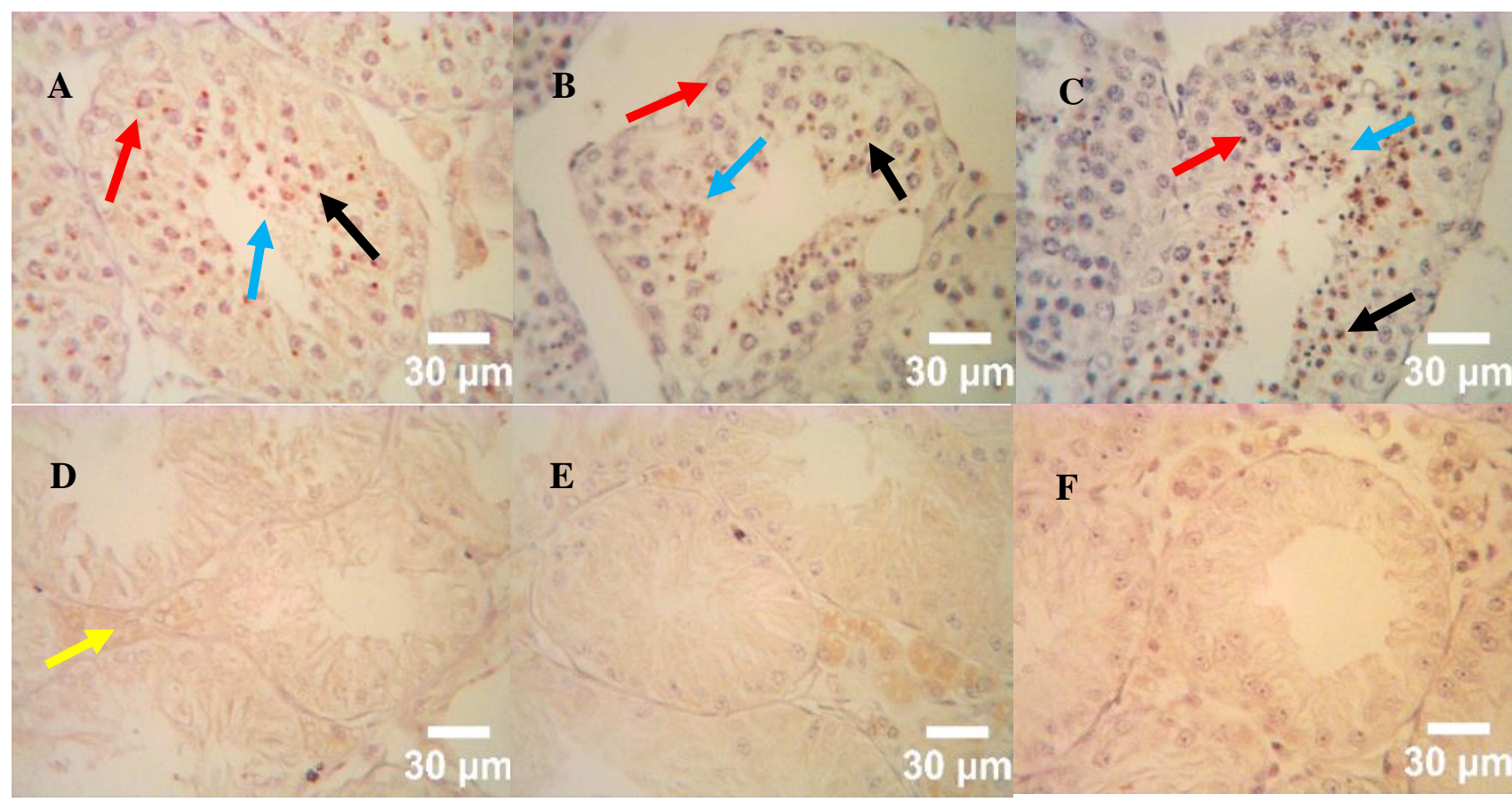

Figure 4. Testicular micrographs of Hystrix javanica (lectin histochemical staining with SJA). A: testicles of mature Sunda porcupine in caput region showing SJA reactivities in primary spermatocyte (red arrow), early spermatid (black arrow) and the late spermatid (blue arrow). B: mature Sunda porcupine testicle in the corpus show SJA reactivities in primary spermatocyte (red arrow), early spermatid (black arrow). C: testicle of mature Sunda porcupine in caudal regions show SJA reactivities in primary spermatocyte (red arrow), early spermatid (black arrow). D: immature testicle in caput show SJA reactivities in Leydig cells (yellow arrow), while show negative SJA-reactivity in corpus (E) and cauda $(\mathbf{F})$.

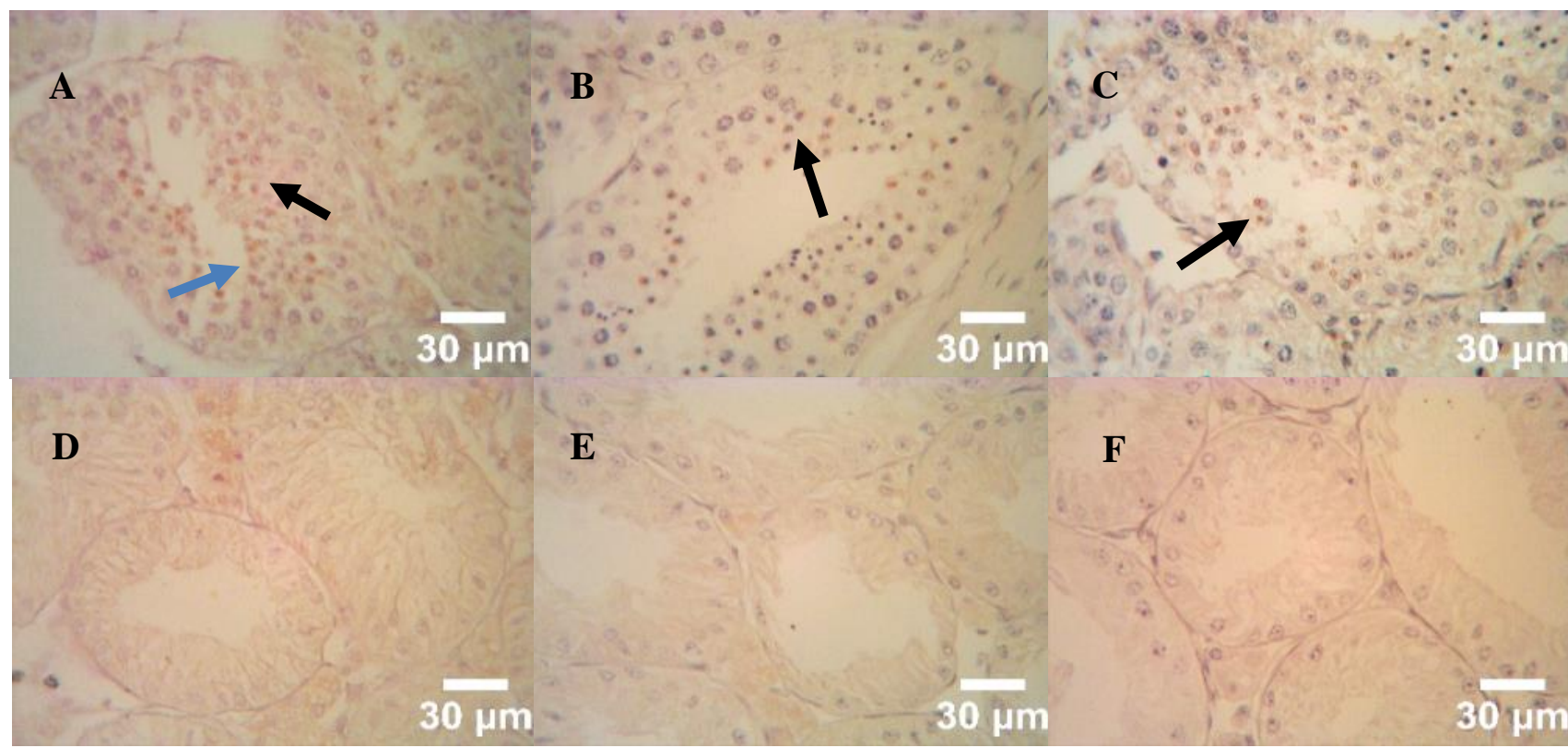

Figure 5. Testicular micrographs of Hystrix javanica (lectinhistochemical staining with WGA). The mature Sunda porcupine testicles in caput (A) and corpus (B) show positive WGA reactivities in early spermatid (black arrow) and the late spermatid (blue arrow). C: the testicle of Sunda porcupine in caudal regions show positive WGA reactivity in spermatids (black arrows). The immature Sunda porcupine in caput part (D) and cauda (F) show negative WGA reactivity, while in corpus region. E: show positive reactivity in the Leydig cells.

\section{CONCLUSION}

In conclusion, the present study showed that lectin histochemical staining with LCA, PHA-L, SJA, PSA, and WGA indicated the presence of alpha-D-mannose and alpha-D-glucose, N-acetylgalactosamine, mannose, and Nacetylglucosamine sugar residues in the immature and mature testes of Sunda porcupine with weak to very strong intensity. In the immature testes, $\mathrm{N}$-acetylgalactosamine may involve in the development and maturation of Leydig and Sertoli cells, whereas in the mature testes, alpha-D-mannose and alpha-D-glucose, $\mathrm{N}$-acetylgalactosamine, mannose, and 


\section{DECLARATIONS}

\section{Authors' contribution}

Teguh Budipitojo developed the concepts and designed the experiments, analyzed and interpreted the data. Irma Padeta collected tissue samples and fixed them in Bouin's solution, processed tissues for paraffin-embedded method. Beninda Ulima Yulianti developed the concepts and designed the experiments, visualized lectin reactivity and wrote the manuscript. Dian Bekti Hadi Masithoh wrote the manuscript and analyzed data. All authors read and approved the final manuscript.

\section{Competing interests}

The authors have not declared any conflict of interest.

\section{Acknowledgments}

The authors are grateful to the Directorate General of Higher Education (DIKTI), Ministry of Research, Technology and Higher Education of Indonesia. (Fund number: 38/LPPMUGM/2015).

\section{REFERENCES}

Ahmed AE (2005). Morphological, Glycohistochemical Studies on the Embryonic and Adult Bovine Testis. LudwigMaximilians-UniversitratMunchen. Munich. Available at: https://edoc.ub.uni-muenchen.de/3978/1/AbdElmaksoud_Ahmed.pdf

Arya M and Vanha-Perttula T (1985). Lectin-binding pattern of bull testis and epididymis. Journal of Andrology, 6: 230242. DOI: https://doi.org/10.1002/j.1939-4640.1985.tb00839.x

Bacha Jr WJ and Bacha LM (2012). Color Atlas of Veterinary Histology. $3^{\text {rd }}$ Edition. A Wolter Kluwer Company, New York, pp. 203-220. Available at: https://onlinelibrary.wiley.com/doi/abs/10.1111/avj.12035

Barre A, Bourne Y, Van Damme EJM and Rougé P (2019). Overview of the structure-function relationships of mannose-specific lectins from plants, algae and fungi. The International Journal of Molecular Sciences, $20(2): 254$. DOI: https://doi.org/10.3390/ijms20020254

Belicky S and Tkac J (2015). Can glycoprofiling be helpful in detecting prostate cancer?. Chemické zvesti, 69(1): 90111. DOI: https://doi.org/10.1515/chempap-2015-0052

De Schutter K and Van Damme EJ (2015). Protein-carbohydrate interactions as part of plant defense and animal immunity. Molecules, 20(5): 9029-9053. DOI: https://doi.org/10.3390/molecules20059029

Dias RDO, Machado LDS, Migliolo L and Franco OL (2015). Insights into animal and plant lectins with antimicrobial activities. Molecules, 20(1): 519-541. DOI: https://doi.org/10.3390/molecules20010519

Feizi TE and Haltiwanger RS (2015). Editorial overview: Carbohydrate-protein interactions and glycosylation: Glycan synthesis and recognition: finding the perfect partner in a sugar-coated life. Current Opinion in Structural Biology, 34:7-9. DOI: https://doi.org/10.1016/j.sbi.2015.10.005

Hernández JM, Seco-Rovira V, Beltrán-Frutos E, Ferrer C, Serrano-Sánchez MI and Pastor LM (2018). Lectin-binding pattern of glycoconjugates during spontaneoustesticular recrudescence in Syrian hamster (Mesocricetus auratus) after exposure to short photoperiod. Andrologia, 51(1): 13148. DOI: https://doi.org/10.1111/and.13148

Aplin K (2016). Hystrix javanica. IUCN Red List of Threatened Species. DOI: https://dx.doi.org/10.2305/IUCN.UK.2016-2.RLTS.T10752A22231749.en

Kobayashi Y, Tateno H, Ogawa H, Yamamoto K and Hirabayashi J (2014). Comprehensive List of Lectins: Origins, Natures, and Carbohydrate Specificities. In: Hirabayashi J (editor) Lectins. Methods and protocols. New York: Humana Press. DOI: https://10.1007/978-1-4939-1292-6_45

Lee MC and Damjanov I (1984). Anatomic distribution of lectin-binding sites in mouse testis and epididymis. Differentiation, 27: 74-81. DOI: https://doi.org/10.1111/j.1432-0436.1984.tb01410.x

Lee MC and Damjanov I (1985). Lectin binding sites on human sperm and spermatogenic cells. Anatomical Record, 212: 282-287. DOI: https://doi.org/10.1002/ar.1092120310

Li Y, Li N, Yu X, Huang K, Zheng T, Cheng X, Zeng S and Liu X (2018). Hematoxylin and eosin staining of intact tissues via delipidation and ultrasound. Scientific Report, 8: 12259. DOI: https://doi.org/10.1038/s41598-01830755-5

Murakami Y, Hasegawa Y, Nagano K and Yoshimura F (2014). Characterization of wheat germ agglutinin lectinreactive glycosylated OmpA-like proteins derived from Porphyromonas gingivalis. Infection and Immunity, 82(11): 4563-4571. DOI: https://doi.org/10.1128/IAI.02069-14 
Nagdas SK, Buchanan T and Raychoudhury S (2014). Identification of peroxiredoxin-5 in bovine caudaepididymal sperm. Molecular and Cellular Biochemistry, 387:113-121. DOI: https://doi.org/10.1007/s11010-013-1876-3

Novelina S, Satryaningtijas A, Agungpriyono S, Setijanto H and Sigit K (2010). Morfologi dan Histokimia Kelenjar Mandibularis Walet Linchi (Collocalialinchi) Selama Satu Musim Berbiak dan Bersarang. Jurnal Kedokteran Hewan, 4: 192. Available at: https://pdfs.semanticscholar.org/c4f7/96e69915163d5084e0d0cce964f50b257057.pdf

Setchell BP (1986). The movement of fluids and substances in testis. Australian Journal of Biological Sciences, 39:193207.

Shegedin A, Yashchenko A and Lutsyk A (2017). Modification of rat testis carbohydrate determinants in postnatal morphogenesis as detected by lectin probes. Journal of Cell Science and Therapy, 8:274.

Verini-Supplizi AG, Stradaioli G, Agioli O and Parillo F (2000). Localization of the lectin reactive sites in adult and prepubertal horse testes. Research in Veterinary Science, 69: 113-118.

Wahyuni S, Agungpriyono S, Adnyane IKM, Hamny H, Jalaluddin M, Gholib, Akmal M, Adam M, Aliza D and Siregar TN (2016). Studi Histokimia Lektin pada Sel-sel Spermatogenik Testis Muncak (Muntiacus muntjak muntjak). Jurnal Kedokteran Hewan, 10 (1): 82-85.

Zhang RY, Neu TR, Bellenberg S, Kuhllcke U, Sand W and Vera M (2014). Use of lectin to in situ visualize glycoconjugates of extracellular polymeric substances in acidophilic archaeal biofilms. Microbial Biotechnology, 8(3): 448-461. DOI: https://doi.org/10.1111/1751-7915.12188 